УДК $821.161 .2-13.09$

\author{
Біляцька В. П., \\ кандидат філологічних наук, доцент \\ кафедри української літератури \\ Дніпропетровського національного \\ університету ім. Олеся Гончара (м. Дніпро)
}

\title{
ЖАНРОВІ ТА ПОЕТИКАЛЬНІ КОНТАМІНАЦІЇ СУЧАСНИХ РОМАНІВ У ВІРШАХ
}

У статті розглянуто романи у віршах початку XXI cm. 3 авторською жанровою номінацією, зокрема роман-пісня «Мама-Марія» Г. Лютого таз уст народу а й болі серия «Віків передзвони» І. Козака, в аспекті жанрової та поетикальної контамінацій, щзо виникають при інтерферениіі творів усної народної творчості і художньої літератури.

Ключові слова: жанр, роман у віршах, контаміначія, фольклор, синтез.

В статье рассмотрены романы в стихах начала ХХІв. с авторским жанровым номинированием - роман-песня «Мама-Мария» Г. Лютого и из уст народа а й боли сердиа «Веков перезвоньы» И. Козака - в аспекте жанровой и поэтикальной контаминации, что возникают $в$ интерференции произведений устного народного творчества и художественной литературы.

Ключові слова: жанр, роман в стихах, контаминация, фольклор, синтез.

The article deals with novels in the verse at the beginning of the twenty-first century with the author's genre nomination novel-song G. Ljutyi «Mama-Maria» and when people say, the heart is in the pain I. Kozak "The tracks of epochs» in the aspect of genre and poetic contamination arising from the interference of works of folk work and Fiction.

Key words: genre, novel in verse, contamination, folklore, synthesis. 
Український роман у віршах кінця XX - початку XXI століття характеризується міжродовими й міжжанровими дифузіями, функціонуванням різноконструктивних моделей, трансформацій, контамінацій, вставних жанрів. Своєрідність новоутворених унаслідок дифузії жанрів реалізує прагнення автора бути самостійним у виборі засобів відтворення задуманого, сприяє свободі та варіативності нарації. За висновками Т. Бовсунівської, межі розрізнення жанрів мінливі, навіть епохи відносної стійкості поетичних систем чергуються з епохами деканонізації та формотворчості. «Будь-який жанр може запозичувати специфічні особливості інших жанрів та істотно міняти свій внутрішній лад і вигляд» [Бовсунівська 2009:8].

Співіснуванням декількох жанрових форм, функціонуванням різноконструктивних моделей та елементів архітектоніки характеризуються романи у віршах 3 таким авторським жанровим визначенням: І. Козак «Віків передзвони» (2001) - з уст народу а ци болі серияя, Г. Лютий «Мама-Марія» (2008) - роман-пісня. У жанровій номінації авторів подано оновлення, самобутність художнього осмислення жанру, яке «nідвищує конкурентоспроможність тексту» [Нестерук 2013:206].

Романи у віршах «Мама-Марія» Г. Лютого, «Віків передзвони» І. Козака є творами, у яких контамінацуія (лат. contaminatio - змішування, схрещування) унаочнює не лише поетикальні сполучення, а й структурні риси інших жанрів, сполучення, що вказують на нерозривний зв'язок із фольклорно-етнічною традицією та національним духовним світом, українською культурою й історією загалом.

Для роману-пісні «Мама-Марія» Г. Лютого характерна настанова на жанровий експеримент, застосування моделей $\mathrm{i}$ форматів іншого жанру художньої літератури - nicнi. Це поетична міфотворчість письменника (поєднання надпобутового в побутовому), україноцентричний роман 3 «агією південного степу» (П. Загребельний), що зародився як своєрідна схема асоціацій-настроїв, це «Біблія українського жстття із піснями-псалмами, сюжетом, невідворотністю пророцтвв» [Біленко 2008:375]. Твір має декілька 
сюжетних ліній, багатий на враження й переживання про життя, про «причетність» до доль земляків. Наскрізний образ твору - Україна уособлений у маминій пісні, піклуванні за кожну людину від народження й аж до Того Світу, коли «знов стаєм ломикаменем» [Лютий 2008:43], у душі людини, у звичаях і традиціях, у народних моральних канонах, це Скарб, на який навіть Господь задивлявся: «Та життя ї̈ так обікрало: / Турки й шляхта, підпанки й пани, / За сльозами невидима стала, / Само-бранкою стала од них [Лютий 2008:40].

У романі у віршах «Мама-Марія» більше п’ятдесяти вставних пісень і «пісеньок» (недарма авторська жанрова номінація - роман-пісня), які уже в назвах несуть ідею твору: «Земле рідна, земличенько...», «Самобранка», «Моя щаслива хатинонько», «Із душі павутинонька...», «Над рікою життя мого», «Наплакало дурне серце кривавую рану», «Як виходили в похід, та й махновці», «Вишня-Всевишня», «Гей, козаче...» «Різдвяні свята» тощо. На думку П. Загребельного, твір Г. Лютого - це «незагойна пісня про матір украӥнського народу, про наших матерів $і$ бабусь, чиї вінчальні сукні зацвітають в скринях $i$ прискринках!» [Загребельний 2008:363]. Пісня в романі - і наскрізний образ, i жанр-вставка, тобто і носій жанру, й ідея твору: «Родило поле намому роду / Пісенний хліб, а щуе - народні рани... [Лютий 2008:42]. Пісні, що співали герої (переважно Марія), вирізняються ліричністю і, головне, відтворенням реалій.

Масштабність зображених подій, багатоаспектність порушених проблем вказують на романну форму «Мами-Марії». Для роману Г. Лютого характерна розгалуженість сюжетних ліній, стрижнем яких є головна героїня Марія, якій Господь подарував спрагу «відчути душу рідного народу». Вона ідентифікується з Божою Матір'ю, Матір'ю українського народу, яка не має ні часових, ні просторових кордонів, і рідною Матір'ю поета. Авторське жанрове визначення роману «Мама-Марія» апелює до образу, який $є$ головною частиною тексту, «включається в образну структуру твору $i$ є вираженням авторської позиції» [Маркова 2012:303]. Марія в романі Г. Лютого виконує функцію об’єднувального ядра, навколо якого зосереджуються всі персонажі - 
Автор, Літописець, Богдан, Скрипаль, Притика, Салій, Вічна Гостя, знахарка Горголя, Гафія, Час, - котрі додають свої вагомі штрихи до літопису тоталітарної дійсності в Україні.

Починається роман-пісня присвятою: «Мамі моїи Марії, роду моєму красному, землякам, тій босоніжній споришевій (від обрію - до колиски) стежиі, щуо привела мене народитися українцем, присвячую...» [Лютий 2008:10], - відповідно й екскурсом у дитинство, спогадами про рідну землю, яка учила простому й вічному. Г. Лютий низько кланяється своїм предкам з Того Світу, які «диктували» й допомагали писати твір: «Bстають допам'ятні вкраӥнці / I ненароджені усі. / У изий, наболеній по віния, / У иій наплаканій красі» [Лютий 2008:11]. Автор тому й звертається до Часу як до свідка всього, що було й що буде. Він із сумом зазначає на початку роману, що на березі Всесвітнього океану Час підготував народові хвилю забуття і щоб цього не сталося, автор вирішив у діалозі-зверненні до читача передати найпотаємніші нюанси людських почуттів і реалій, вчиться бути літописцему нього: «Перед Твоєю сповіддю я голий. / Лише у двох ми здатні оживать! / В Тобі усі, з ким мав і хліб, і постіль, / Обличчя мами, татове плече. / Ти в світ пустив мене, спасибі, в гості, / Мені Вкраїна піснею пече [Лютий 2008:14].

Доля Марії є типовою для багатьох українців XX століття. Із мешканців хутора не «зосталось ні душі», усі померли від голоду, врятувалася лише Марія. Героїня була серед тих небагатьох, хто, дочекавшись «лободи», вижила й заспівала пісню, яка на генетичному рівні з покоління в покоління передавалася в родині, за це їх і прозвали Стоголосі. Марія не уявляла життя без пісні, у якій «висока» мова й щось «святе»: «Вірите, безсила, я давно б здалася, / Якби тої пісні та й не напилася. / Мама в час останній теж заповідала, / Щоб пісні я людям намі заспівала.. / Я й мовчу - співаю, як ота діброва. / Кожна нова пісня - для душі обнова» [Лютий 2008:14].

Контамінація в романі Г. Лютого передбачає жанрові сполучення, що виникають при інтерференції творів усної народної творчості і художньої літератури, зберігає сліди різних джерел, засвідчує синтез рівнозначних 
мистецтв. «Мама-Марія» Г. Лютого - синкретичний роман, бо $є$ своєрідним «сплавом народної думи, поеми, героїчного епосу, баладної оповіді, казкових та фантастичних мотивів» [Дігай 2008:367]. Так, особливо відчутне взаємонакладання фольклору й високого поетичного авторського слова, $\epsilon$ сторінки тексту, на яких згадано декілька фольклорних жанрів. Наприклад, насторінці 274 - забавлянка, колискова, замовляння, казка.

Частина «На Бочанському мосту» - це цикл жартівливих частівок про життя односельців одного 3 кутів, а «Борщ варила...» - історія про велику родину Богдана, яка сприймається як легенда про народження дітей: «Встала боршъику зварити - / Чоловіка покорити. / Та й пішла я по капусту, / А там діток густо-густо: / I окаті, і кирпаті... / Зупинилась я на Каті... / A пішла по бараболю, / Глип, у ній пустує Коля... / По буряк я щ̧е ходила. / Був там вибір щзе з Христин - / Не могла не принести... / А як рвала я горох, / Упіймала зразу трьох: / Олю, Йванка, ще й Софійку - / Каверзуху-довговійку. / Доки монялася зними / Бог послав мені Якима, / A верталась по окріп, / То знайшовся щуе й Охрім. / Так допоки борщз варила, / Вісім діточок зловила» [Лютий 2008:48]. Пісня «Самобрака» - це інтерпретація легенди про найкращу у світі «країну», Україну, яку навіть Бог собі обрав.

Як уже зазначалося, у романі «Мама-Марія» більше п’ятдесяти пісень, які сприймаються не як жанр-вставка, а як поетичний епос про тяжку долю високодуховного народу. Пісні й «пісеньки», як їх означив поет, стилізовано під літературні й фольклорні - «Очі чорні», «Знов коло мами вишня зацвіла...», «Косили косарики», «Хміль», «За рікою дві могили», «Вже красне сонечко...» тощо, - піддано переробці, «змішано» 3 авторською нарацією про трагічні події в Україні, а саме: «Цвіте терен...» - «Цвіте терен, терен цвіте / Щедро в Україні - / Як волосся посивіле / На малій дитині... / Ту зозулю, щзо кувала, / В ланцюг закували. / Тих синочків - як листочків - / Голови на палях!» [Лютий 2008:69]; «Котигорошко» - «B cmeny зоряній вишиванціi, / Щастям кликаний всі часи, / Народився син та й у бранки - / В Україноньки зі сльози. ... / 
Змію голови всі розбиті, / Хто супроти ще - тільки лжа. / Розпинали хлоп'я неситі, / Що Вкраӥнонька та й чужа!» [Лютий 2008:313].

Особливою виразністю характеризуються пісні про махновську вольницю, коли «Червоні ц̆ білі сунули степами... / А з Гуляй-Поля виступав Махно» [Лютий 2008:304] проти «голоду і долі» - «Тарпан», «Махно - цар, Махно - Бог...», «Як виходили в похід, та й махновці...», «Столиця степів», «Чорний прапор», «Махновська», «Шаблі».

Протягом усього роману ми зустрічаємося із носієм народного епосу, кобзарем у різних іпостасях. На початку роману він кобзар-пророк, на ярмарку сповістив, що скоро степ «криваво запалає», будуть зміни у суспільстві. У кінці роману співець жалібно грає в Каневі, «кланяється Тарасу», і йому, кобзареві, й автору сумно від того, що втрачається слухач пісні, мало кого цікавить минуле: «А де ж народ? Хто слухатиме ліру? / Хто тій бандурі сльози повтира?» [Лютий 2008:345].

Т. Біленко аргументовано доводить, що в романі-пісні Г. Лютого подано значущі (од колиски до останнього пристанища) події в житті народу. «Це весілля, толоки, рибна ловля, вечорниці, святкові гуляння, поминки... I подані вони, як правило, не лише енциклопедично вичерпно, а й з допомогою схожих на насіння твоєї душі поетичних образів, передбачаючи майбутнє воскресіння із літописного слова» [Біленко 2008:385].

«Мама-Марія», за означенням Г. Лютого, - це «солодке перевантаження душі» сльозами, світом, любов’ю, що, окрім понадчасової магії, розкриває конкретний час і контекст історії - події громадянської війни, голодомор, більшовицьке виорювання домовин, нищення українського Слова, руйнування храмів («Смерть дзвона»). У романі-пісні автор не лише репрезентував духовність української нації, а вказав i на недоліки: довірливість, безпам'ятство, «розвінчав правду», що сльози землі, горе, від якого божеволіли жінки принесли ті, хто «ізроду нивки не орали, / П'яниці і бездушні жебраки...» [Лютий 2008:340]. 
Автор у творі поставив завдання: «Відчути душу рідного народу, / Omy любов, з якої ти з’явивсь» [Лютий 2008:17], - і 3 цим завданням майстерно впорався, створив поетичну епопею, зафіксований факт буття народу, у якому епіка перетікає в лірику, а лірика не визнає ніяких хронікальних рамок, у черговий раз художньо «відкрив» «брехливість тоталітарної ідеологї, зокрема тієї, яка дістала назву офічійної правди» [Гундорова 2013:177].

Головною ознакою манери письма I. Козака, відомого сучасного закарпатського письменника, Л. Повх назвала одвічну народність, яка зблискує відточеною гранню в романах у віршах «Віків передзвони», «Покута», «Прозріння», «Сповідь» [Повх 2013:13]. Народність стилю автора проявляється не лише у відтворенні етнобуття закарпатців, описі звичаїв і традицій, уведенні в текст народнопоетичних зразків, вживанні різноманітних фольклорних віршованих форм, а й через реальність зображення життя українського народу, щире співчуття його тяжкій долі.

Роман у віршах «Віків передзвони» I. Козака - це «доторк до минувшини». За жанровим визначенням автора - це твірз уст народу а й болі серияя, у якому поєднано суб'єктивні узагальнення народних легенд і переказів i «суб 'єктивність суто індивідуального погляду» [Федака 2001:5]. У сучасному авторському домінуванні жанру виділяється певна тема, яка розкривається у творі і в «грі з читачем», що $є$ однією 3 ознак постмодерністської естетики. Після ознайомлення 3 назвою i жанровим визначенням читач «вибудовує передбачену модель розвитку сюжету, додумує те, щчо, можливо, не розказано автором, таким чином є співавтором читаного тексту» [Нестерук 2013:205].

Твір вирізняється панорамністю та хронологічною послідовністю зображення подій через тісно переплетені сюжетні лінії, наявність справжніх, історичних персонажів, що дає підстави визначити жанр твору як історичний роман у віршах. У той же час Д. Федака писав, що для поетичного епосу I. Козака характерна «довга співанка-балада, чотири-п'яти-иести рядкові наспіви, старовинна колядка, блискітка-коломийка» [Федака 2001:6], які є ядром образного й ритмічного ладу. 
Структурно роман у віршах нагадує народну думу: складається із «Заспіву» («заплачка»), основної частини («власне думи») й «Виспіву» («славословіє»), у творі переважають дієслівні рими, чітка й хронологічна фабульність, описова манера оповіді, яка має потужний ліричний струмінь (авторські відступи, ототожнені 3 своєрідними філософськими рефлексіями, лаконічні пейзажні замальовки, проникнення у внутрішній світ героя), яскраво виражений прийом ретардації (уповільнення розповіді через вкраплення авторських відступів, непередбачувану зміну віршованого розміру).

Але ж твір «Віків передзвони» автор номінував не лише як роман $у$ віршах, а й з уст народу а й болі серия, бо він присвячений побутовим життєвим подіям невеличкого села Тур'я-Ремета Закарпатської області, зокрема постаті сільського листоноші Федора Фекети, якому односельчани на знак вдячності за самовіддану і часто безкорисливу працю в ХІХ столітті встановили пам’ятник. Цей витвір народної глибокої поваги й досі дивує не лише його краян, а й увесь світ, до того ж, не існує аналогів таких пам'ятників. Саме легенди та перекази про славетного земляка письменник взяв за основу роману у віршах і вирішив: «...Розповісти всьому світу, / Бодай лем краянам, / ...Як переказують / Та й із легенд, / Й не без фантазї̈, / Жив був єден / Дідо в Підгаїні» [Козак 2001:20]. Зі спогадів старожилів відомо, що Федір Фекета обслуговував дільницю каретно-поштового зв'язку, що охоплювала майже всю Турянську долину. Щодня листоноша, якого тоді шанобливо називали «послом», долав близько 60 кілометрів, доставляючи землякам 3 Ужгорода газети, листи, грошові перекази тощо. Шлях пролягав через гори, струмки іріки, не раз зустрічав він ведмедів і рисей, але завжди вчасно приносив пошту. Проте його все ж спіткала біда: перегрівшись у дорозі, він напився гірської крижаної води, тяжко захворів (інша версія - провалився під лід) і помер від запалення легенів. Селяни не забули легендарного листоношу: на фасаді місцевої церкви 3'явилася меморіальна дошка 3 барельєфом сільського поштаря 3 написом: «Федор Фекета. В пам'ять приязности, тверезности, чесности, послужности посла». Меморіальна дошка на стіні храму збереглася до наших днів, а в 2000-х 
Федору Фекеті спорудили пам'ятник у закарпатському райцентрі Перечин (скульптор - заслужений художник України Михайло Белень).

Відображення життєвої правди засобами фольклоризму в романі «Віків передзвони» має як традиційні, так і цілком індивідуально-авторські особливості. Поняття фольклоризму в художньому творі розглядається в кількох понятійних площинах, ми ж акцентуємо на таких, як історичне явище, що відображає певний рівень світогляду суспільства в ту чи ту епоху i втілюється в мистецьких контамінаціях двох художніх систем; як одна із стадій i форм функціонування фольклорного матеріалу, що диктується іманентним розвитком словесного мистецтва; як явище, що виникає в процесі творчого освоєння фольклорного матеріалу індивідуальною творчістю в межах літературного твору [УФСД 2008:400-401].

Роман у віршах «Віків передзвони» I. Козака - це контамінація народнопоетичних жанрів, фольклоризмів у літературному тексті, коли, орієнтуючись на фольклорну поетику, автори художніх творів трансформують, переосмислюють чи розбудовують традиційно фольклорні мотиви, образи, композиційні схеми та художні засоби у канві власного тексту.

Полівимірність фольклоризму передбачає відповідний підхід до його вивчення. Це функціональний аспект: використання фольклорного елемента на стильовому, жанротворчому, системотворчому рівнях; трансформація фольклорем на формальному ізмістовому рівнях; зближення 3 фольклорним джерелом, уснопоетичною естетикою та поетикою. У романі у віршах Івана Козака - це:

- відтворення конкретних етапів звичаєвості та обрядовості (весілля, хрестини, поховання, проводи в рекрути, святкування Різдва, Великодня, Покрови), народних ігор, забавок («Дубак», «Судця»), використання народних спостережень-прикмет;

- застосування фольклорної стилізації, постійних епітетів, метафор, порівнянь та інших тропів (найпродуктивніше епітетів: ясні зорі в небі світять, синій Дунай, явір молоденький, ведмідь бурий, сонечко ясненьке, коні чорні 
ŭ вороненькі), синонімічних фольклорних пар, тавтологічних зворотів (отияматері, дівка-відданиия, циганка-парадниия, циарь-король, моря-океани тощо), назв сакральних рослин (дуб, явір, вільха, верба, вінки, сплетені з ялини), що використовують під час обрядодій, художнього паралелізму; введення у текст живої народної мови 3 чітко діалектним колоритом (зображуються події конкретного закарпатського села певного часу з особливостями соціального, національного устрою);

- у фольклорній традиції подано портретні характеристики героїв (Ілони); вживання слів із зменшено-пестливими суфіксами як засобів ідеалізації героїв, віддзеркалення їхнього внутрішнього стану та підсилення ліризації оповіді: циганочка, зозулечка, співаночки, земелька, вдовичя, дитятко, раненько, соколонько, додомоньку, правдонька тощо.

У романі у віршах «Віків передзвони» не просто згадується про якийсь звичай, обряд, а детально художньо ідентифікується підготовка й проведення його. Як сценарій народного дійства сприймається реципієнтом опис весілля 3 дійовими особами, вставними піснями, побажаннями: «Довкола весілля: / Знай собі гуляють, / Свашки за повір'ям, / Дві гуні чіпляють. / Навпроти, де сіли / 3 а стіл молодята, / Аби не вдовіли / I були багаті...» [Козак 2001:145]. Майстерно й колоритно обігрується колядування: «Вже Різдво. Десь колядують, / Щастядоленьку вінчують» [Козак 2001:109]. Це своєрідна ремінісценція історії про народження Ісуса Христа, початок якої є авторською стилізацією народного зразка на Закарпатті, - прихід Пастиря з братами, який просить дозволу повідати про подію у Віфлеємі. Основна частина близька до фольклорного варіанта різдвяного колядування, в якому використано контамінації загальновідомих колядок, цитат з Євангелія, які є змістовою і структурною складовою, i народного святкування, i тексту роману. Кінцівка дійства закінчується колядкою, у канву якої вплетено ім'я адресата - коханої Федора Ілонки: «лонко-душко! Колядка довга. / На вік здоров'я / Так би сьте ся мали, / Як земля в Русали» [Козак 2001:120]. 
У спогадах про Великдень відтворено й підготовку до свята, i його відзначення, наприклад, таӥнство писанкарства, обряд освячення паски на Великдень, обливання у Великодній понеділок. Поетична сюжетна лінія твору постійно переходить у пісню, баладу, народний плач, до того ж, настільки гармонійно, що досить складно відокремити створене автором від оригінального фольклорного зразка. Наприклад, тости-побажання: «- Наливайте, любі гості! / Най росте Катка велика / Мамиці, няньові на втіху. / Най минає всяке лихо, / Хижа повна буде сміху» [Козак 2001:80]; голосіння Федора Фекети за дідом: «-Ой дідику милий, / Лем ня не лишайте / Вже мало спочили... / Вставайте, вставайте! / Землиця студена, / Та я вам поможу... / Їміться за мене / Не вмирайте прошу» [Козак 2001:42].

Головними критеріями змісту роману $є$ насамперед морально-етичні норми, за якими живуть герої твору та шукають відповіді на питання: «Чому, Боже, отак люди / В гріховнім шаленстві / Сатаніють, душі гублять / Для миті блаженства?» [Козак 2001:66]. Герої дотримуються й пропагують християнську мораль: читають молитви, ходять на сповідb, моляться не лише в храмі, а й у каплиці. А в скруті завжди щиро прагнуть допомогти тому, хто поруч, хто по-справжньому любить свою землю й готовий стати на іï захист, хто вміє віддано кохати, як головні протагоністи Федір та Ілона.

Варто погодитися 3 думкою К. Левченка, що роман у віршах «Віків передзвони» є справжнім поетичним закарпатським дивом: «пісенно-трагічний епос частки України, щзо тривалий час була відірвана від загалу, але оберегла себе від поглинання сусідніми народами» [Левченко 1999:16]. Як уже зазначалося, роман у віршах I. Козака багатий на контамінації різних народнопоетичних жанрів, у яких переважають сумні мотиви. Це й співанки, i рекрутські, i заробітчанські пісні, невеселі мотиви й у весільних піснях, адже дівчину віддають за нелюба. Чергування пісень, використання традиційних фольклорних зачинів на кшталт «Полетіла зозуленька...», «Ой летіли гуси 3 далекого краю», «Ой за тою за горою» створює особливий темпоритм оповіді, рухає або ж уповільнює сюжет, розвиток дії, уможливлює авторський висновок: 
«Пам'ять зіткали ми / з сонячних струн, / Й пісня цчимбалами - / Вічності сум» [Козак 2001:172].

Народний струмінь роману у віршах I. Козака, його ідея, проблематика та художня форма зрозумілі й дорогі кожному свідомому українцю, адже в них закодована глибока історична пам’ять, яка застерігає та захищає людину від перетворення на манкурта та ренегата.

Отже, романи у віршах «Мама-Марія» Г. Лютого та «Віків передзвони» I. Козака є творами, у яких контамінація наявна не лише на поетикальному, а й жанровому рівнях. В авторській жанровій номінації творів подано оновлення, самобутність осмислення жанру - роман-пісня, з уст краян а ц̌ долі серия, синкретизм фольклорної і літературної пісень, суб’єктивне узагальнення легенд i переказів. Твори характеризуються реальністю зображення життя українського народу на Півдні й Закарпатті, його тяжкої долі, особливо за часів тоталітарної дійсності, вказують на нерозривний зв’язок із фольклорноетнічним духовним світом.

\section{БІБЛІОГРАФІЯ}

Біленко 2008 - Біленко Т. Яйце-райце українського духу / Т. Біленко // Лютий Г. I. «Мама-Марія» (роман-пісня). - Запоріжжя : Дніпровський металург, 2008. - С. 372-386.

Бовсунівська 2009 - Бовсунівська Т. В. Теорія літературних жанрів : Жанрова парадигма сучасного зарубіжного роману : підручник / Т. В. Бовсунівська. - К. : ВПЦ «Київський університет», 2009. - 519 с.

Гундорова 2013 - Гундорова Т. Транзитна культура. Симптоми постколоніальної травми : статті та есеї / Т. Гундорова. - К. : Грані-Т, 2013. 548 с. (Серія «Deprofundis»).

Дігай 2008 - Дігай Т. Крапля роси 3 каменю / Т. Дігай // Лютий Г. I. Мама-Марія (роман-пісня). - Запоріжжя : Дніпровський металург, 2008. C. 369-370.

Загребельний 2008 - Загребельний Павло. Дорогий наш український читачу / П. Загребельний // Лютий Г. I. «Мама-Марія» (роман-пісня). Запоріжжя : Дніпровський металург, 2008. - С. 363. 
Козак 2001 - Козак І. Ю. Віків передзвони : 3 уст краян а й болі серця : Роман у віршах / І. Ю. Козак / Передм. Д. Федаки. - Ужгород : Вид-во В. Падяка, 2001. - 184 с.

Левченко 1999 - Левченко Кость. Плач Закарпаття : Нотатки про поетичний роман у Івана Козака / К. Левченко // Свобода. - 1999. - № 4 (22 січня). - С. 16.

Лютий 2008 - Лютий Г. I. Мама-Марія (роман-пісня) / Г. І. Лютий Запоріжжя : Дніпровський металург, 2008. - 392 с.

Маркова 2012 - Маркова Т. Авторские жанровые номинации в русской прозе конца XX - начала XXI века / T. Маркова // Мова і культура. (Науковий журнал). - К. : Видавничий дім Дмитра Бураго, 2012. - Вип. 15. - Т. V (159). C. $299-303$.

Нестерук 2013 - Нестерук В. В. О некоторых особенностях малих жанров русской реалистической прозы конца XX - начала XXI века / В. В. Нестерук // Вісник ЛНУ імені Тараса Шевченка. - Луганськ : ЛНУ, 2013. - № 9 (268). Ч. II. - C. 202-208.

Повх 2016 - Повх Л. Сторінки минулого. До ювілею І. Козака / Л. Повх // Новини Закарпаття. - 2016. - № 101-102. - С. 13.

УФСД 2008 - Українська фольклористика. Словник-довідник / Уклад. і заг. редакція М. Чорнопиского. - Тернопіль : Підручники і посібники, 2008. $448 \mathrm{c}$.

Федака 2001 - Федака Д. Доторк до минувшини / Д. Федака // Козак I. Ю. Віків передзвони : 3 уст краян а й болі серця : Роман у віршах . - Ужгород : Вид-во В. Падяка, 2001. - С. 5-12. 